\title{
Joaquim Manuel de Macedo, historiador e dramaturgo
}

Joaquim Manuel de Macedo, historian and playwright João Cícero Teixeira Bezerra

João Cícero Teixeira Bezerra Pós-doutor em Artes Cênicas pela Universidade Federal do Estado do Rio de Janeiro (Unirio)

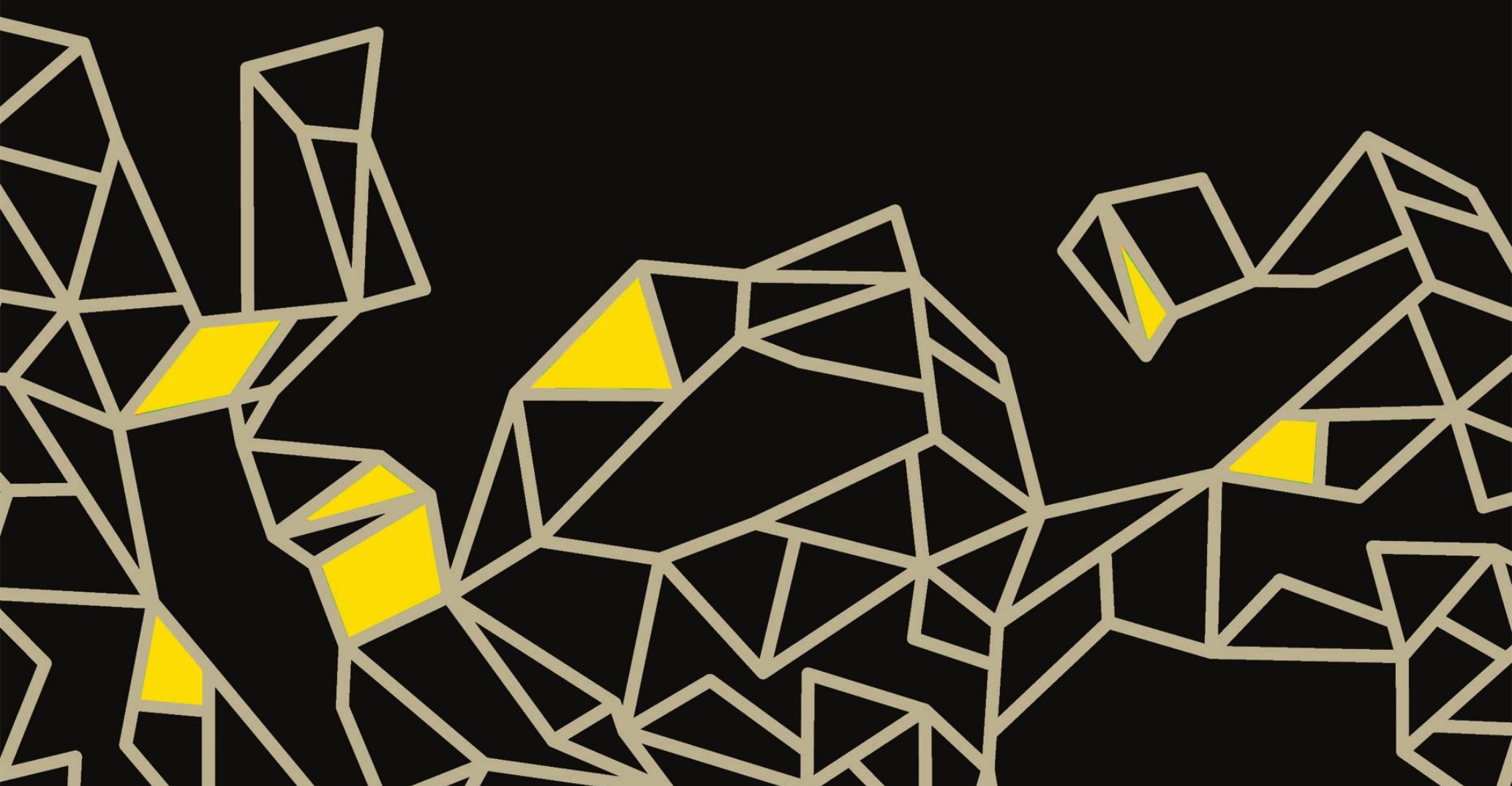




\section{Resumo}

Este artigo discute o trânsito da produção historiográfica e dramatúrgica de Joaquim Manuel de Macedo em sua lida com questões caras ao debate entre teatro e história. Nessa direção, analisa-se o livro didático Lições de história do Brasil e a peça teatral Cobé. A partir de uma leitura das obras se esclarece o quanto o pensamento do escritor se deixa permear pela formatação textual de cada veículo, abrindo-se em interpretações distintas. Para a análise das obras, agenciam-se leituras de textos teóricos e historiográficos com o intuito de elucidar a relação entre escrita histórica e ficcional na obra do autor. No caso estudado, verifica-se como o período colonial e o tema indianista ganham cores distintas e pragmática específica em cada obra.

Palavras-chave: História da historiografia, Nacionalismo, Romantismo.

\section{Abstract}

This article discusses the transit between the historiographic and dramaturgical production of Joaquim Manuel de Macedo in dealing with issues that are central to the debate between theater and history. In this direction, the didactic book Lessons on the History of Brazil (free translation) and the play Cobé are analyzed. From a preliminary reading of the works, it is clear how much the writer's thought is permeated by the textual formatting of each communication vehicle, opening itself up for different interpretations. For the analysis of the works, the reading of theoretical and historiographic texts is required in order to elucidate the relation between historical and fictional writing in the author's work. In the case studied, we can see how both the colonial period and the Indianist theme gain distinct approaches and specific pragmatics in each work.

Keywords: History of historiography, Nationalism, Romanticism.

\section{Introdução}

O título do artigo é provocativo por refletir sobre uma atividade pouco conhecida e estudada de um notório escritor do século XIX, contrastando-a com outra prática de sua escrita ${ }^{1}$. Sabe-se bastante de seu exercício como

1 Artigo produzido em pós-doutorado no PPGAC-Unirio (Bolsa CNPq-PDJ), linha de pesquisa História e Historiografia do Teatro e das Artes/Supervisão dra. Maria de Lourdes Rabetti. 
romancista, cronista e comediógrafo, mas pouco do historiador-educador. O intento deste texto é analisar como Joaquim Manuel de Macedo (1820-1882) lidou com um período histórico específico, a época colonial, em duas obras de ambição e formatação distintas: um manual de história do Brasil e uma peça teatral.

Formado em medicina, Joaquim Manuel de Macedo trabalhava no Imperial Colégio Pedro II como professor de história e geografia e ocupava um cargo de primeiro-secretário no Instituto Histórico Geográfico Brasileiro (IHGB). Dessas funções derivam os livros Lições de história do Brasil (1861) e Noções de corografia do Brasil (1873), sendo o primeiro um manual de ensino da disciplina, de que fazia uso a fim de ministrar suas aulas aos estudantes da instituição do Império, enquanto o segundo é uma encomenda para a Exposição Universal de 1873.

No Brasil da virada do século XIX para o XX, momento em que ainda não existiam os cursos universitários de História, as regras do discurso historiográfico e o lugar por excelência para o desenvolvimento de uma escrita e reflexão sobre o passado remetiam para o Instituto Histórico e Geográfico Brasileiro (IHGB), instituição que foi e continua sendo objeto de diversos estudos sobre a escrita da história no Brasil oitocentista. (CALDEIRA; MACEDO, 2016, p. 43)

No artigo citado, as pesquisadoras Adriana Mattos Clen Macedo e Ana Paula Sampaio Caldeira (2016) comentam o fato da ausência de especialização do discurso historiográfico na virada do século XIX para o XX no Brasil, uma vez que não havia cursos universitários de formação profissional na área. A atividade girava, no caso de Ramiz Galvão, em torno de "diversas instituições de saber imperiais e republicanas, como o próprio IHGB, mas também a Biblioteca Nacional (BN), o Colégio Pedro Il e a Academia Brasileira de Letras (ABL)" (Ibid., p. 44). Em Macedo, observam-se semelhanças, pois se trata de um escritor cujo trânsito passa pelo IHGB e pelo Imperial Colégio Pedro II.

$\mathrm{Na}$ obra de Macedo, o cruzamento entre a produção do historiador e a do ficcionista produz aspectos relevantes para a análise das obras aqui estudadas: Cobé (1854) e Lições de história do Brasil (1861). Serão debatidos aspectos como o levantamento dos fatos pelo escritor-historiador e o modo como o historiador se transforma dentro de uma mesma temática em 
produções distintas: o drama e a história. Partindo dessa análise comparativa, veem-se as contradições do pensamento de Macedo diante do texto histórico e ficcional e compreende-se a ambiguidade do ethos desse importante intelectual público do século XIX em temas relevantes de nossa história.

Esforços contemporâneos vêm aos poucos trazendo à tona a faceta de Macedo como historiador. No decorrer deste artigo apresentaremos algumas pesquisas importantes nessa direção, marcando, a partir das exposições e comentários desses trabalhos, as diferenças de nossa abordagem - que não é polêmica, mas contribui com a divulgação de diferentes e novos aspectos do pensamento de Joaquim Manuel de Macedo.

Seguindo nessa direção, destacamos a dissertação de Rafael de Almeida Daldro Bosisio (2007), Entre o escritor e o historiador: a história do Brasil imperial na pena de Joaquim Manuel de Macedo. Nela o historiador parte da hipótese de verificar um elo entre a ficção e a produção historiográfica de Macedo considerando a formação deste como médico. Assim, percorre como fontes para sua análise da obra desse autor: "os romances, principalmente A moreninha e Um noivo a duas noivas; as crônicas; a tese de medicina; o artigo, os relatórios e os discursos produzidos no Instituto Histórico e Geográfico Brasileiro e publicados na revista do próprio instituto" (Ibid., p. 3). Já na introdução de seu trabalho, o pesquisador justifica a ausência da dramaturgia de Macedo em sua dissertação:

As peças de teatro não foram trabalhadas por uma questão de tempo para a execução do trabalho, visto que, além de existir uma bibliografia específica para análise de peças teatrais, essa parte da obra do escritor está no mesmo sentido de seus romances, como, por exemplo, o tom moralizante e o final feliz. (Ibid., p. 3-4)

De fato, o tom moralizante dos romances persiste nas peças teatrais. Todavia, não se pode afirmar que o final seja sempre feliz no caso das obras dramáticas de Macedo. Por exemplo, o drama histórico Cobé (1854) não traz um desfecho venturoso para o protagonista. O mesmo se sucede em outras peças, como em sua comédia $O$ novo Otelo (1863), em que a anedota moral estabelecida em torno do ciumento Calisto (o "Otelo") é irônica e, por fim, o personagem fica só, sem se casar com Francisca. 
A hipótese de Bosisio (Ibid.) segue um caminho genealógico. Ela parte de uma semelhança procedimental entre os campos de conhecimento da história e da medicina nos Oitocentos, observando como o ofício de historiador e a formação de médico se entrelaçam na ficção e na produção historiográfica de Macedo. Em busca de "status social" Macedo faz medicina, e essa formação, nunca exercida, Ihe serviria para "atuar em outras áreas", como na história (Ibid., p. 84) - o que não é estranhável no caso do século XIX, uma vez que, como diz o historiador em sua dissertação, existe tanto na medicina como na história "uma busca pelo diagnóstico para prescrever um tratamento" (Ibid., loc. cit.). Em sua conclusão, o autor reitera essa aproximação genealógica que liga o ofício de Macedo como historiador e ficcionista à ideia da "perda" presente já na tese monográfica do bacharel em medicina. Assim, a "perda" torna-se uma imagem semântica sempre presente nos textos de Macedo. Ela é, grosso modo, o diagnóstico do médico-historiador-romancista, que será tratada pelo sentimento de nostalgia.

Como se observa, a aproximação entre ficcionista e historiador segue direções diversas no trabalho de Bosisio e no nosso. A interpretação de Bosisio (Ibid.) se edifica na formulação de uma biografia intelectual de Macedo que busca a convergência da obra do autor com uma ideia base ("perda"), percorrendo a gênese de formação do historiador-romancista como médico e vendo nela um encontro de forças. Este artigo parte da análise de duas obras que poderiam ter se homogeneizado pela similitude temporal (a época colonial) e pelo recorte temático (indianista), mas que vistas lado a lado apresentam contradições e ambiguidades do ethos intelectual de Joaquim Manuel de Macedo. Deve-se reforçar que nosso olhar em nada contradiz o de Bosisio; apenas se constrói como uma alternativa complementar de análise para que se esclareça o debate em torno da relação entre a escrita historiográfica e a de ficção no século XIX no Brasil.

\section{As lições: a naturalização civilizatória da história}

O livro Lições de história do Brasil surge com a seguinte indicação: "para uso dos alunos do Imperial Colégio de Pedro Segundo" (MACEDO, 1861, p. 1). A recomendação expressa claramente o caráter utilitário e o interesse 
didático da obra, que se autonomeia na terceira página como compêndio, isto é, resumo, síntese da história do Brasil.

Em trabalho de grande pioneirismo em que analisa as duas primeiras edições de Lições de história do Brasil, a historiadora Selma Rinaldi de Mattos (1993, p. 105) nos faz ver como Macedo, no trânsito dessas duas versões, "cumpria um outro papel fundamental: o papel de uma expansão" didática de seu projeto pedagógico. Expansão de uma ideia de nação praticada pelo Imperial Colégio Pedro II, um laboratório civilizatório da recente e imperial nação brasileira. A pesquisadora nos apresenta esse quadro por meio de um levantamento extenso de fontes e da leitura esmiuçada das duas publicações de Macedo - uma primeira voltada aos alunos do Imperial Colégio Pedro II e uma segunda dirigida aos "alunos de todas as escolas de instrução primária do Império" (Ibid., p. 105).

Mattos também nos diz o quanto o livro História geral do Brasil (1854), de Francisco Adolfo de Varnhagen (1816-1878), se constitui como fonte principal de Macedo no que concerne "especialmente [à] verificação de fatos e datas" (Ibid., p. 98). Logo, o empenho de Macedo na elaboração de suas Lições de história era muito mais pedagógico do que de pesquisa e verificação de fontes. Acerca da questão institucional da criação de duas importantes obras historiográficas nos Oitocentos, a historiadora nos informa que:

Em 1854 Francisco Adolfo de Varnhagen publicava o primeiro volume da sua História Geral do Brasil, concretizando um dos fins por que havia sido criado o Instituto Histórico e Geográfico do Brasil. Sete anos depois, Joaquim Manuel de Macedo publicava as suas Lições de História do Brasil, procurando concretizar a outra finalidade daquela instituição. (Ibid., p. 51)

A primeira obra estabelecia uma ideia geral de nação, enquanto a segunda punha essas ideias em lições. No gesto de Macedo havia também uma crítica ao método Lancaster (que formara a geração do próprio historiador), em que os alunos maiores ensinavam os menores, havendo assim certa desigualdade dos conteúdos ministrados ${ }^{2}$. Desse modo, Lições de história do Brasil tinha como objetivo a fixação programática do ensino de história

2 Método de ensino mútuo e monitorial criado pelo inglês Joseph Lancaster (1778-1838), trazido e aplicado no Brasil desde 1823 por Dom Pedro I (MATTOS, 1993). 
da nação imperial brasileira, empenho sedimentado pelo IHGB (Ibid., p. 54). Nota-se, consequentemente, como uma rede de forças políticas e institucionais do presente de Macedo se inscrevem na obra aqui analisada.

Professando desde alguns anos a história do Brasil no Imperial Colégio Pedro II, reconhecemos no fim da breve experiência que se fazia sentir a falta de um compêndio dessa matéria que fosse escrito e metodizado de harmonia com o sistema de estudos adotado naquele importante estabelecimento, e também compreendemos que a nós, como professor da cadeira respectiva, cumpria mais que a outro qualquer satisfazer uma tal necessidade. (MACEDO, 1861, p. 5)

A fala institucional revela a ambição de Macedo de pôr em livro um método em harmonia com o sistema educativo da escola imperial. Escola cuja elaboração curricular obedecia a parâmetros elitistas, destinando-se a formar a pequena parcela abastada da sociedade brasileira da época. "O Colégio D. Pedro II era uma escola destinada à formação das elites de uma sociedade agrária, escravista e patriarcal, com um ensino informativo e enciclopédico que refletia as ideias europeias já há muito tempo superadas" (SECO, 2006, p. 10). O livro de Macedo em nada foge do padrão enciclopédico, conforme relata Ana Paula Seco em seu artigo "A educação que emerge dos livros de viagens", como traço próprio do sistema educacional adotado pelo Imperial Colégio Pedro II. Todavia, merece destaque o modo como o historiador-educador organiza seu livro didático.

Para efeito de análise, nos circunscreveremos à primeira edição do livro, de 1861, de Joaquim Manuel de Macedo. A obra continuou sendo refeita e publicada em várias outras edições atualizadas (até postumamente, quando coube ao editor o arremate e a atualização do livro) ${ }^{3}$. No manual de 1861 , indicada no índice ao fim do livro, observa-se a seguinte divisão:

$$
\begin{aligned}
& \text { Prefácio } \\
& \text { Lição } 1 \text { - Considerações Preliminares } \\
& \text { Lição } 2 \text { - Descobrimento do Brasil } \\
& \text { Lição } 3 \text { - Primeiras explorações }
\end{aligned}
$$

3 Refiro-me à edição de 1905 da obra publicada pela livraria Garnier. Tal edição póstuma traz acontecimentos que chegam ao século XX. Já era a nona edição do livro. 
Lição 4 - Cristóvão Vasques e Martin Afonso de Souza

Lição 5 - O Brasil em geral - povos que habitavam na época de seu descobrimento

Lição 6 - Sistema de colonização do Brasil empregado por D. João III

Lição 7 - Primeiros donatários de Capitanias hereditárias no Brasil

Lição 8 - Estabelecimento de um governo geral no Brasil: Thomé de Souza - primeiro governador geral

Lição 9 - Duarte da Costa - Segundo governador geral do Brasil

Lição 10 - Mem de Sá - Terceiro governador geral do Brasil

Lição 11 - Divisão do Brasil em 2 governos, subsequente reunião em 1 só. Domínio Espanhol. (MACEDO, 1861, p. 145)

A primeira data relatada no livro é 1385, quando nas "Considerações Preliminares" o historiador narra a posse de D. João como rei de Portugal, e segue acompanhando a formação deste país e sua constituição como nação de grande poder náutico. O último registro é de 1581. Esse percurso cronológico do livro visita o primeiro século da colonização brasileira. Verifica-se que, para além da ordem diacrônica dos fatos, Macedo se circunscreve a um entendimento que liga a história ao registro de datações. Toda a análise e os comentários do historiador são orientados pelos acontecimentos em torno de datas, sempre registrando feitos e conflitos que ligam reis e conquistadores ao povo: escravizados, índios ou colonos rebeldes. De fato, a história que se conta é da relação de Portugal com o Brasil, e essa primeira edição não chega a tratar do período imperial, mas da constituição de um domínio português europeu e da fixação da colônia. Do ponto de vista da nomeação dos capítulos, nota-se que o historiador varia entre acontecimentos históricos e nomes próprios para a narração em seu manual.

D. João, o mestre de Avis, filho natural de D. Pedro, o Justiceiro, tinha sido, por morte de seu irmão D. Fernando, em 1385, proclamado rei de Portugal pelas Cortes ou estados gerais do reino, e havia firmado inabalavelmente o seu trono na famosa batalha de Aljubarrota, triunfando de D. João I de Castela, que Ihe disputava.

O novo rei de Portugal via-se rodeado de filhos ardentes e belicosos, e também entrava nos cálculos de sua política o não dar tempo a arrefecer os ímpetos guerreiros do seu povo: a paz fatigava o monarca, os príncipes e os vassalos, e em falta de agressão [...] atendeu aos infantes que Ihe propunham a conquista de Ceuta. (Ibid., p. 7) 
Da primeira página do livro à última, não se vê um historiador neutro distribuindo fatos históricos com reserva e sem qualquer juízo de valor, e no transcorrer de nosso artigo mostraremos como Macedo se posiciona diante de hipóteses históricas, discordando de trabalhos de referência em seu tempo. Como observa-se no trecho citado, em um parágrafo Macedo resume os acontecimentos que fizeram D. João (mestre de Avis) tornar-se rei de Portugal, para em seguida interpretar a conquista da cidade de Ceuta como produto da vontade do monarca de demonstrar sua força e domínio, causando intenso impacto em seus infantes.

A interpretação é política e ao mesmo tempo parte de uma construção ético-psicológica da figura do rei, conforme expressa na obra $O$ príncipe, de Nicolau Maquiavel, na qual a figura do monarca deve ser dotada de grande temeridade e firmeza. O historiador Joaquim Manuel de Macedo não só enumera fatos, mas os interpreta mediante a lógica de um pensamento político que sustenta as ações históricas do soberano.

Eu responderia que um príncipe poderoso e afoito superará sempre aquelas dificuldades, ora dando aos súditos esperança de que o mal não será longo, ora incutindo temor da crueldade do inimigo, ora assegurando-se com destreza daqueles que lhe pareçam muito temerários. [...] Donde, em se considerando tudo bem, não será difícil a um príncipe prudente conservar firmes, antes e depois do cerco, os ânimos de seus cidadãos, desde que não faltem víveres nem meios de defesa. (MAQUIAVEL, 2010, p. 44)

Ao narrar os feitos de D. João, o historiador fez também considerações subjetivas, como "a paz fatigava o monarca" (MACEDO, 1861, p. 7). Na lógica expressa de seu pensamento, o rei teve de se lançar à conquista de Ceuta com o intuito de se apossar da confiabilidade de seus súditos. A guerra é, portanto, um motor de manutenção do poder pelo soberano. Do mesmo modo, Macedo se posiciona em um conjunto discursivo historiográfico que entende a guerra de Ceuta como marco do início de Portugal como nação europeia de status imperial ${ }^{4}$.

4 Kátia Brasilino Michelan (2013), em sua tese de doutorado Ceuta, para além da terra dos mouros: a fabricação histórica de um marco do império português (século XV e início do $X V I)$, faz uma interessante revisão crítica sobre a discursividade expansionista vinculada à conquista dos ceutas. Segundo a autora, há uma construção historiográfica que visou interpretar Portugal como uma potência náutica, confirmando a lógica de domínio colonial da nação europeia. 
No final do livro, quando apresenta o domínio espanhol sobre Portugal, Macedo persiste em sua hermenêutica da relação de poder entre o monarca e o povo: "fácil em prometer quando tratava de chegar aos fins que visava, Felipe II confirmou as leis e os privilégios da nação portuguesa; assegurou que nem levantaria novos impostos nem aumentaria os antigos" (Ibid., p. 142). Para reinar e manter seu poder, um rei é capaz de abdicar de uma política exploratória com a finalidade de construir uma negociação de domínio com o povo conquistado, ou seja, faz tudo para realizar seus fins, como pressupõe Macedo.

Não se pode esquecer que Joaquim Manuel de Macedo vive num regime monárquico e faz seu manual de história para os alunos do Imperial Colégio Pedro II. Registrar a lógica dos reis e suas negociações "acertadas" com o povo não é se imbuir de uma crítica anticonformista contra o status quo. Trata-se, ao contrário, de legitimar os espaços de poder e mostrar como um bom governo deve ser firme para chegar "aos fins" almejados.

Ao narrar as ações pouco louváveis dos governantes, Macedo justifica sua necessidade. Há dois fatos que firmam a visada moral e conformista do historiador. O primeiro, e mais evidente, é que o historiador fazia parte da engrenagem de poder institucional que era a monarquia brasileira. Como se diz em ditado popular, Macedo era "amigo do rei". O segundo aspecto se deve à sua visão naturalizada da história, que se coaduna com a lei de consanguinidade da monarquia. Esse entendimento de mundo naturalizado está presente tanto em seu drama trágico Cobé quanto nas Lições de história do Brasil. Entretanto, Macedo não chega a supor um modelo de sociedade imóvel por conta de sua fé nas ideias civilizatórias, que agiriam como "medicamento/ensinamento" social, conforme os argumentos de Bosisio (2007).

Na quinta lição, "O Brasil em geral - povos que habitavam na época de seu descobrimento, o historiador se detém nas qualidades físicas do Brasil, sua geografia, geologia, aves, peixes etc. Como o historiador é formado em medicina, o linguajar científico lhe é familiar, conforme se verifica em sua descrição da fauna e da flora do país. Ao falar do indígena que habitava a terra antes de esta ser tomada pelos europeus, Macedo apresenta argumentos provindos de teses raciais: 
Estes caracteres físicos que em geral ajustam a todo o gentio do Brasil parecem indicar que a sua raça provém do mesmo tronco da mongólica; esta questão, porém, está ainda por decidir e se mostra sempre duplamente duvidosa: em relação à ciência até mesmo a pluralidade das raças tem sido negada: em relação ao fato nada há de positivo que demonstre e explique a origem asiática da raça americana. Um dilúvio, um cataclisma separando da Ásia a América, uma emigração há séculos passados realizada são tudo hipótese; mas de hipóteses não passaram ainda (MACEDO, 1861, p. 60)

Certamente essas hipóteses lhe chegavam pelo debate etnográfico do IHGB. Em sua tese Tempos cruzados: escrita etnográfica e tempo histórico no Brasil oitocentista, Rodrigo Turin nos apresenta o debate em torno do trabalho do paleontólogo e arqueólogo dinamarquês Peter Wilhelm Lund (1801-1880), que discorre acerca da aproximação entre os mongóis e algumas tribos indígenas brasileiras (TURIN, 2009, p. 71-77). Macedo revela seu desconforto com essas teses que circulavam explicando a origem do índio brasileiro e a mistura das raças. Na passagem, fica evidente o movimento de Macedo de não aderir à hipótese da vinda do índio da Mongólia, apresentando-a com distância e reforçando seu caráter duvidoso ${ }^{5}$.

Ainda sobre a questão racial no livro de Macedo, torna-se relevante perceber como o autor via por meio de uma justificativa "social" (enquanto falta de civilidade) a rudeza dos povos indígenas, desligando, assim, o comportamento do índio de um determinismo racial, como expresso em teses racialistas de cunho científico-determinista.

Todos estes usos e costumes denunciam um povo na sua infância, homens rudes e selvagens, alheios à civilização; mas de nenhum modo [...] incapazes de alguns nobres e generosos sentimentos.

Vivendo vida de guerras e combates, [...] o gentio do Brasil habituou-se à vingança, e quando a exercia, requintava na crueldade, levando-a até a antropofagia (que, aliás, em algumas tribos não se observava), mas por maior que fosse o gosto que achasse nesses horrorosos banquetes,

5 Francisco Adolfo de Varnhagen, em seu livro História geral do Brasil, está certamente de acordo com a tese de Lund: "Nada mais natural do que acreditar que, por várias partes, o chamado novo-continente não deixou de ter tido comunicação com o antigo; já depois de primitivamente povoado por gentes da mesma raça mongólia do oriente da Ásia" (VARNHAGEN, 1854, p. 54). Assim, a dúvida lançada por Macedo acerca da hipótese da vinda do indígena brasileiro da Mongólia revela que o historiador não adere com facilidade à tese do paleontólogo dinamarquês. 
jamais devorou um que não fosse de inimigo. Era antropófago por vingança. (MACEDO, 1861, p. 65-66)

Essa concepção do indígena em sua infância também está presente em Francisco Adolfo de Varnhagen: "de tais povos na infância não há história: há só etnografia. A infância da humanidade na ordem moral, como do indivíduo na ordem física, é sempre acompanhada de pequenez e de misérias" (VARNHAGEN, 1854, p. 22-23). Entretanto, em Macedo se observa um abrandamento no discurso, pois a ideia de homens não civilizados, selvagens e de um "povo em sua infância" é amenizada pelo fato de os índios possuírem "nobres e generosos sentimentos" (MACEDO, 1861, p. 65-66); enquanto para Varnhagen a qualificação é "acompanhada de pequenez e de misérias" - universo semântico distinto. $\mathrm{O}$ canibalismo de algumas tribos é também explicado e justificado como atitude de vingança contra o inimigo. $O$ selvagem não pratica antropofagia gratuita, mas sim uma espécie de ação "política" territorial necessária. Ao falar de um "antropófago por vingança", o historiador deixa escapar certa afeição pelo nativo que aqui habitava antes da chegada dos portugueses.

De fato, o escritor oitocentista interpreta o indígena por meio de sua moral cristã civilizatória, em que o "nobre sentimento" e a antropofagia "por vingança" indicam o solo fértil de aculturação do índio pelo homem branco como será praticado pelos jesuítas catequizadores.

A temática indígena era, como nos mostra a pesquisadora Maria Regina Celestino de Almeida em seu artigo "Os índios na História do Brasil no século XIX: da invisibilidade ao protagonismo", uma questão bastante recorrente na política e na intelectualidade brasileira do século XIX. Porém a insistência no assunto visava civilizar o indígena, isto é, adaptá-lo à moral do colonizador, uma vez que o protagonismo daquele e a ação pedagógica no campo dos estudos se inclinavam "a um mesmo fim: a ocupação das terras indígenas e a transformação de seus habitantes em cidadãos e eficientes trabalhadores para servir ao novo Estado" (ALMEIDA, 2012, p. 24-25). Logo, quando Macedo apresenta em seu livro de história do Brasil esse perfil do povo nativo, deixa escapar sua ideologia de colonizador, apesar de elucidar e justificar a ação do índio antropófago.

No modo como Joaquim Manuel de Macedo narra os episódios históricos, vê-se uma operação comumente adotada pela historiografia oitocentista: 
o entendimento da história como um fenômeno civilizatório e evolutivo. Evoluir para o autor significa, pois, aproximar-se do modelo de civilização construído pelo homem europeu. A esse respeito, Michel Foucault comenta em seu livro A arqueologia do saber (1987, p. 41): "no século XIX, o tema evolucionista se refere [...] à descrição de grupos descontínuos e à análise das modalidades de interação entre um organismo, cujos elementos são solitários, e um meio que the oferece suas condições reais de vida".

Perceber o indígena como "um povo na sua infância" é como estabelecer (por descrição) uma descontinuidade entre ele e o padrão europeu, considerado mais evoluído para o historiador. Desse modo, o conceito de evolução ligado à ideia de história formula-se pelo entendimento da "História" (sempre com maiúscula) como um contínuo prosseguir abstrato em busca de um ideal de civilidade que reúne séries descontínuas (os indígenas, a fauna, as línguas etc.) em uma ideia de nação.

Em outro livro escrito por Joaquim Manuel de Macedo, Noções de corografia do Brasil (1873), que não é o centro das especulações deste ensaio, ao descrever os espaços geográficos do país e os efeitos da colonização o autor faz a seguinte consideração:

A conquista e a colonização do Brasil disputada aos portugueses pelas hordas selvagens que o habitavam foi obra difícil, penosa e longa para a qual concorrerão três elementos todos consideráveis, e cada um dirigido por intenção especial: a ação do governo; a catequese jesuítica; e o gênio aventuroso e indomável dos sertanejos paulistas. (MACEDO, 1873, p. 7)

Descrevendo o domínio territorial do vencedor (o povo português), Macedo não deixa de enumerar a "intenção especial" de cada batalha. Logo, os marcos são acontecimentos revestidos de intencionalidade e praticados por sujeitos volitivos. Lembremo-nos do comentário feito acerca da interpretação dada pelo autor aos atos dos reis, muito aproximável de uma visão maquiavélica e fixada em sua relação estreita com o poder institucional do Império do Brasil. Do mesmo modo, os espaços são fundados mediante a mesma operação de domínio. Fundam-se povoações e fortalezas após a conquista das terras.

O significativo é perceber como, nesse modelo utilizado por Macedo (de narrar uma teleologia do vencedor), reside um entendimento abstrato da história 
do homem civilizado em fricção e descontinuidade com o povo colonizado e explorado que habitava a terra. Descontinuidade experimentada pelo pré-conceito de um narrador (da história) que entende como inevitável a adaptação do índio (de bons sentimentos) aos valores civilizados do homem branco.

Em sua tese, Rodrigo Turin (2009) nos mostra que o grande dilema que se deflagra com a questão indígena é a "ordenação do tempo". O índio "teria seu lugar na medida em que era o habitante primitivo do território, antes da chegada dos portugueses" (Ibid., p. 37). Ou seja, falar de uma história do território brasileiro era incluir o nativo, já que ele era entendido como parte constituinte da "natureza primitiva" dessa história. Entretanto, o "grande problema desse período, para esses letrados, era o fato de que não havia documentos escritos que permitissem esclarecer sua história" (Ibid., loc. cit.). Assim, trazendo novamente as lições de Macedo, podemos dizer que o indígena era incluído num modelo de história igualmente natural e naturalizador, que os via como "um povo na sua infância" (MACEDO, 1861, p. 65).

Selma Rinaldi de Mattos (1993) nos esclarece acerca do empreendimento pedagógico de Macedo. Ele, como um historiador romântico, "estava interessado em narrar para cada um dos seus jovens leitores a 'biografia da Nação brasileira', desde o seu 'nascimento' (o descobrimento) até a 'fase adulta' [...] (a independência do Brasil)" (MATTOS, 1993, p. 105). Logo, a construção discursiva desse historiador passa pela naturalização da ideia de civilização (e da história), uma vez que, para ele, há fases de desenvolvimento civilizatório, como no organismo humano. $O$ índio seria como uma criança que deve ser educada, civilizada. Em analogia, o aluno, a quem o livro é destinado, deve entrar em contato com uma história civilizatória para se tornar um bom cidadão. Assim, atrelado completamente à visão historiográfica de seu tempo e certo de seu privilégio institucional e civilizatório (no lugar de fala de um homem adulto), Macedo constrói Lições de história do Brasil.

Nessas lições, o indígena é certamente um tema-problema para se situar a história do Brasil, relativo às origens da recente nação. É também uma alteridade "natureza" a ser aculturada (cristianizada também) de modo produtivista, pois sua cultura é vista como danosa, e sua rebeldia se justifica, para o historiador, apenas como própria de sua etapa civilizatória, a infância. Tal infância é ordenada também pela concepção de um tempo processual cientificista ("de 
um progresso contínuo e infinito"), amparada na ideologia de uma história da salvação, conforme aponta Giorgio Agamben (2008) em Infância e história: destruição da experiência e origem da história, como sendo a concepção de tempo oitocentista. Assim, o índio deveria ser educado (como território ocupado) para satisfazer um historicismo que, no século XIX, "esconde na realidade uma radical negação da história em nome de um ideal de conhecimento moldado nas ciências naturais" (Ibid., p. 118).

Nota-se, pois, como Macedo (médico e historiador) se orienta, em Lições de história do Brasil, por essa regra historiográfica oitocentista: a exclusão de uma concepção de história repleta de experiências e sentidos contrastantes provenientes das temporalidades do indígena e do brasileiro, escolhendo a ordenação de um tempo homogêneo conformado no conhecimento das ciências naturais.

\section{Cobé: a retórica indianista e o tema da escravização}

Cobé (1852) é um drama indianista que narra a história de amor mal correspondido do índio Cobé pela fidalga Branca, apaixonada por Estácio, mas prometida por seu pai, Dom Rodrigo, a Dom Gil. O desencontro das paixões e o fato de o indígena se submeter à condição de escravizado por amor a Branca são os temas centrais da peça. O anacronismo dado ao tema da colonização portuguesa, a edificação de um drama histórico cuja ambientação de época se sustenta sem fato definido e o uso de diálogos retóricos são o que compõem a urdidura da trama elaborada pelo dramaturgo-historiador aqui estudado.

O início da peça traz a seguinte indicação: "a cena se passa no Rio de Janeiro, nos primeiros tempos da época colonial" (MACEDO, 1979, p. 3). Não é a espacialidade que se destaca na obra. O que causa impacto é o fato de Macedo montar seu drama indianista com uma tensão trágica: o amor do índio e da fidalga não se concretiza, e o desejo e a paixão de Cobé são irrealizáveis. Sua morte suicida é uma espécie de destino trágico (punição de seu desejo) e ao mesmo tempo representa liberdade para Branca e seu amor por Estácio, uma vez que Cobé assassina Dom Gil.

A peça segue por meio de uma divisão episódica em cinco atos, possuindo cada ato uma titulação poética (e, em parte, autoexplicativa) dos acontecimentos 
que se dão no palco: "Ato I: a praguejadora"; "Ato II: a escolha do confidente"; "Ato III: o sarau"; "Ato IV: o anjo da morte"; "Ato V: Cobé por Branca".

No primeiro ato, sabemos do amor de Cobé pela moça Branca e do desprezo da matriarca indígena, Agassamu, pela indolência dele ante as guerras enfrentadas pelos índios contra os portugueses. No segundo ato, Cobé e Branca se encontram, mas o índio não consegue falar dos seus sentimentos e acaba apenas ouvindo de sua amada acerca de sua paixão por Estácio. No terceiro ato, o título não se explica necessariamente como lição moral como nos outros, pois se refere a um acontecimento que se dá na casa de Dom Rodrigo, um sarau; do ponto de vista dos acontecimentos dramáticos, o que ocorre realmente é a conversa de Dom Gil com Dom Rodrigo e, posteriormente, com Cobé sobre sua insatisfação acerca do amor de Branca por outro homem, no caso, Estácio. No quarto ato, Branca vai até Agassamu e pede a ela um veneno, pois prefere morrer a ter que se casar com Dom Gil. No quinto ato, Cobé retira de Branca o anel com o veneno, bebe seu conteúdo, mata Dom Gil, confessa seu amor pela jovem e morre após libertá-la.

A peça deve ser pensada em duas direções: a temática indianista e a escravocrata. $O$ discurso de liberdade se encontra na fala do indígena, entretanto, não há possibilidade de Cobé se libertar de sua condição de escravizado. Por isso seu amor não pode se concretizar com a fidalga Branca, cabendo-lhe como gesto final libertá-la, punindo-se com o suicídio expiatório ao tomar, no lugar de sua amada, o veneno fabricado por sua mãe, Agassamu, para a morte de Branca.

O anacronismo presente na obra se dá pelo seguinte ponto: Macedo constrói uma peça cujo tema está ancorado na luta entre o índio e o português colonizador, contudo, sua obra foi escrita no Brasil escravocrata do século XIX e espelha o entendimento daquela sociedade acerca da escravidão como um mal necessário ${ }^{6}$. O discurso de liberdade e luta do indígena dono da terra não

6 O historiador Luiz Felipe Alencastro (1997, p. 91) comenta em seu ensaio "Vida privada e ordem privada no Império" sobre As vítimas algozes de Macedo: "de vítimas os escravos passavam a ser algozes; era preciso se desembaraçar deles, largá-los na natureza". Comentando o fato de Macedo ser abolicionista e, ao mesmo tempo, ter em sua posição uma ambígua visão dos escravizados africanos, o historiador nos apresenta um quadro cultural em que um defensor da liberdade dos escravizados africanos aconselha que eles deveriam ser entregues à natureza. É possível, em consequência disso, que as ideias de Macedo tragam um componente racialista de entendimento do escravizado africano como um ser pertencente à natureza selvagem. 
rompe os grilhões de sua condição de escravizado. Assim, essa condição torna-se materialidade na tragédia de Cobé. Não há possibilidade de liberdade para o ser selvagem, exceto ao fugir para a natureza ou ser entregue a ela. Por esse inexorável destino, ele acaba sublimando sua paixão em sacrifício.

\section{Dom FUAS.}

Quando o direito assiste de castigar, Cobé; e esse eu não tenho. Vós outros nos desertos vos puníeis. Sem juízes, sem leis, sem fundamentos; o ofendido matava; e essa vingança era entre vós a punição do crime. Mas conosco outro tanto não sucede; temos um rei e chefes, que governam, e a quem cumpre fazer geral justiça.

COBÉ.

E chama-se justiça o que sofremos?!!!

D. FUAS.

Já confessei que abusos se praticam; só o poder do tempo há de vencê-los. No entanto a causa santa que abraçamos, avante levaremos; para bem vosso acesa ficará no mundo novo a luz, que amostra o céu, e aqui plantada da redenção a cruz, a lei do Cristo.

COBÉ.

E um Deus, que é só de paz, pregais com a guerra? Crenças, senhor, o sangue não fecunda.

D. FUAS.

Mas quando a estupidez foge à verdade, é justiça obrigar a conhecê-la. Queríeis que depois de esforços tantos, olvidando as mais doces esperanças, de novo atravessássemos o oceano, deixando-vos nas garras do pecado, e a terra de Cabral imersa em trevas?...

COBÉ.

A terra de Cabral?!!!

D. FUAS.

Sim: que te espanta?...

COBÉ.

A terra de Cabral?!!! Um navegante, que açoitado por fera tempestade, como a esponja, que o mar arroja às praias, sem o pensar, à terra ignota chega, tem jus acaso à possessão alheia?... A terra era já nossa e o será sempre. Quem, e com que direito ousou doar-lha?!!! A terra é de quem nasce sobre a terra. $O$ deserto é do tigre e do selvagem. Vós outros que deixais vossas cidades e inda à vossa ambição os campos faltam, pedi... nós vô-los damos... sobras temos; Mas a terra, senhor, não, não é vossa. (MACEDO, 1979, p. 18-19) 
No trecho citado se vê um debate político e retórico de um fidalgo, Dom Fuas, com o índio Cobé. Atente-se, pois, às justificativas de cada parte. $\mathrm{O}$ colonizador acredita que é capaz de libertar o ser selvagem de seus hábitos primários por meio da luminosidade racional de suas leis, fé e governo. $O$ índio, no entanto, argumenta contra, questionando a propriedade da terra e a justiça instituída pelos portugueses que faz os indígenas sofrerem enormemente em cativeiro; e, sem necessariamente pôr em dúvida o Deus cristão, Cobé não o vê como o responsável por guerras tão atrozes.

Em ensaio que historiciza a questão simbólica da antropofagia no Brasil no romantismo, no modernismo e no tropicalismo, João Cezar de Castro Rocha observa em uma nota explicativa de Ubirajara (1874), de José de Alencar, a elaboração da "escrita de uma história alternativa com base numa releitura antropofágica dos relatos dos cronistas coloniais" (ROCHA, 2011, p. 650). Nessa nota o escritor romântico associa o gesto de vingança do indígena canibal à imagem cristã de "comunhão da carne", compreendendo no gesto antropofágico não a "pequenez" sentenciada por Varnhagen, mas interpretando-o como gesto cristão, assim como defende Macedo acerca da alma e dos sentimentos nobres dos indígenas antropófagos.

Essa relação, apesar de ligada a fontes não tão aproximáveis no tempo (Cobé, 1854; Lições de história do Brasil, 1861; e Ubirajara, 1874), nos faz pensar como no romantismo se praticava uma espécie de filtro cristianizador do indígena por uma via sentimental e reflexiva que alterava determinados lugares comuns - já mostramos a diferença entre Macedo e Varnhagen no que tangencia essa questão. Rocha vê também na nota de Alencar uma "ideia-força eminentemente positiva, subvertendo, assim, a interpretação usual" (Ibid., loc. cit.). Nos dois casos, essa positividade se agencia pela via do paralelismo com o cristianismo. Como se vê, Joaquim Manuel de Macedo, ao lidar com a estrutura dialógica do teatro por meio da fala (e da empatia) de Cobé, abriu-se para a percepção crítica do indígena enquanto indivíduo dominado por um povo que veio de longe e tomou conta de sua terra, impondo leis próprias que não eram coerentes com o que pregavam como fé.

Diferentemente da narração histórica do manual do Imperial Colégio Pedro II, observa-se uma abertura discursiva em Macedo, através da ficção, no que se refere ao lugar do indígena no período colonial. No livro didático 
o indígena era visto como o ser selvagem de bom coração, que matava e se alimentava de suas vítimas por vingança. No manual, a fala empática do historiador não é comparável com a ficcionalização do discurso de Cobé, que apresenta, de seu lugar dramático, a perda de "direito" sobre a terra sofrida pelos índios com a chegada dos portugueses.

"As relações de sentido entre os diferentes enunciados assumem índole dialógica (ou, em todo caso matiz dialógico). Os sentidos estão divididos entre vozes diferentes" (BAKHTIN, 2003, p. 320). Mikhail Bakhtin parte da interpretação de enunciados que não são formados por meio de uma construção lógica. Neles verifica-se a necessidade de uma interpretação que pressuponha a relação de diálogo entre as partes. Não se deve, pois, para entendê-los seguir o princípio de uma lógica formal rigorosa. Antes, cabe perceber que eles se dão por uma índole dialógica, ou seja, há na construção do sentido a presença de vozes que podem se revelar diferentes.

Macedo não era um intelectual que praticava apenas um tipo de escrita. Sua figura de homem público se dividia em uma série de práticas textuais. Logo, para captarmos sua visão histórica, seu ethos público, faz-se necessário adentrar na seara dialógica de suas obras, registrando as diferentes dicções e tratamentos dados por ele a um mesmo período histórico - como se faz aqui com a época colonial no texto de ambição didática Lições de história do Brasil e no texto dramático-ficcional Cobé. Como se pode observar, a obra dramática acaba apresentando devido à sua liberdade ficcional, no que se refere ao lugar do colonizador português como usurpador da terra, uma capacidade de reflexão maior do que o trabalho didático, que não incorpora a visão do indígena sobre a terra.

Machado de Assis (1961, p. 32) em sua crítica à peça de Joaquim Manuel de Macedo em 11 de setembro de 1859, na Revista dos Teatros, diz o seguinte:

Os dramas são de mestre. Um pincel adequado traçou com talento caracteres, desenhou a situação, e no meio de grandes belezas chegou a um desfecho sanguinolento, nada conforme com o gosto dramático moderno, mas decerto o único que reclamava a situação. É um escravo que ama a senhora, e que se sacrifica por ela - matando o noivo que lhe estava destinado, mas a quem ela não amava decerto. Essa moça, Branca, ama, entretanto, um 
outro; e Cobé, o pobre escravo - a quem uma sociedade de demônios tirara o direito de amar, quando reconhecia (ainda hoje) o direito de torcer a consciência e as faculdades de um homem, Cobé sabe morrer por ela.

Em toda a apreciação de Machado de Assis da peça Cobé, o crítico não se refere ao personagem principal como um indígena. Tampouco nos apresenta o contexto da obra que se passava no período colonial. Apenas a palavra "escravo" é repetida pelo crítico. O fato deve ser levado em conta tendo em vista que o regime escravocrata vigorava na ocasião da montagem. Há nessa recepção de Machado um aspecto relevante. A tematização da escravidão via drama edificava um discurso de identificação em que a escravidão tinha duas vias: Cobé era escravizado por ser índio e pelo amor. Porém tal condição reforçada pelo drama importava mais que o contexto histórico apresentado de modo claro pelo dramaturgo.

COBÉ (olhando com desprezo para Dom Gil).

Eu nada mais receio. Agora não os temo; o meu cadáver terão somente, e ao muito com abutres dilacerá-lo podem: tal vingança digna é de meu desprezo, e digna deles. [...] A morte se aproxima. Mortal veneno em minhas veias gira; urge o tempo. (MACEDO, 1979, p. 79)

Outro drama que se encarregou de tocar no tema da escravização, sendo igualmente elogiado por Machado de Assis, foi o texto Mãe, de José de Alencar (1862, p. 143).

JOANA

É um atrevimento!... Mas eu queria antes de morrer... beijar sua... sua testa, meu nhonhô!...

JORGE

Mãe!...

JOANA

Ah!... Joana morre feliz!

JORGE

Abandonando seu filho.

JOANA

Nhonhô... Ele... Ele se enganou!... Eu não... Eu não sou tua mãe não... meu filho! (Morre). 
As obras apresentam dois personagens principais que não se sentem capazes, em decorrência da condição de escravizados, de viver seus sentimentos e relações humanas com plenitude. Amar a fidalga para Cobé é sua tragédia e sua prisão; ser chamada de mãe por Jorge é o martírio de Joana. Ambos se suicidam em sacrifício e por amor, dando a liberdade ao ente querido. Nas peças a própria condição da escravização é trágica na medida em que não há possibilidade de liberdade. Mesmo a alforria dada pelo filho à Joana não transforma seu destino. Ela está, como Cobé, enclausurada na condição de escrava.

Esses casos refletem o imaginário aristocrático dos autores, visto que aprisionam seus personagens em condições trágicas, não transformáveis. A fuga, no caso de Cobé, ou a alforria, no caso de Joana, são possibilidades especuladas no interior das fábulas, porém não são adotadas como saída pelos ficcionistas. Grosso modo, sabe-se que a tragédia lida com as questões do destino, inelutável, sendo o drama a forma com que o conflito se desenvolve através de uma estrutura dialógica em função da inter-relação dos personagens (SZONDI, 2001, p. 29-34). No caso dessas obras, as possibilidades de transformação são oferecidas tanto para Cobé, pela ideia de fuga e revolta dada por Agassamu, quanto para Joana através da alforria. Mas essa liberdade não é aceita por ambos.

Caso seguissem o domínio da inter-relação dialógica (isto é, as possibilidades elucidadas por outros agentes) do drama, os personagens poderiam ter se libertado da condição de cativos. Entretanto, é no interior do personagem, em sua não aceitação como ser de igual direito em relação aos outros personagens livres e libertos, que se emoldura seu destino trágico através do suicídio - o qual se dá enquanto sacrifício.

O tema da escravização (do indígena) no drama de Macedo não difere do tratamento dado à escrava Joana em Alencar. Essa não diferença formal é, pois, matéria de análise para entender o porquê de dois contextos históricos distintos serem representados, do ponto de vista simbólico, de modo similar no século XIX: o período colonial e a contemporaneidade da escravização no Império do Brasil. Na estrutura dramática e em seu desenlace notam-se enormes semelhanças entre as obras. Tal aproximação reflete o quanto Macedo forja seu drama indianista, sustentado ainda por um sentimento conservador diante 
da condição do escravizado - que não consegue se libertar, mas já pode expor seu drama humano. A retórica do indígena contra o colonizador português que Ihe usurpou a terra demonstra uma amplitude maior de juízo historiográfico do Macedo dramaturgo diante do Macedo historiador. Mas essas duas faces compõem um pensamento que está em diálogo em função de um mesmo tema, abrindo-se e fechando-se segundo pragmáticas textuais distintas. Entretanto, o sentimento de inferioridade em Cobé e seu sacrifício cristão em prol do amor da fidalga Branca revelam sua submissão essencialista de cativo. Nesse sentido, a retórica indianista questionadora da propriedade da terra difere do tratamento dado ao tema da escravização, que segue uma progressão de acontecimentos na qual só é possível a expiação do índio pela liberdade de sua amada.

Em seu livro História do teatro brasileiro, Edwaldo Cafezeiro e Carmem Gadelha (1996, p. 175) chamam essa obra de "drama da consciência" pelo modo como a dramaturgia se debate diante dos dilemas morais de Cobé. Causa estranhamento que um personagem com tamanha inteligência crítica como Cobé, ao se sentir rejeitado por Branca, sacrifique seu sentimento para salvar a amada, pois sem revolta passional (ciúmes), ele livra a jovem de um casamento arranjado pelo pai, mas sepulta seu desejo em um desfecho trágico, ou seja: a liberdade é dada à fidalga e o suicídio é experimentado pelo escravizado. Macedo, em sua obra, cria um personagem de reflexão crítica aguda, mas de instintos e paixões cristianizados. Nota-se assim o quanto esse drama se inscreve na mentalidade oitocentista: os escravizados cabiam a chibata, a venda e o aluguel de seus corpos, passando seu direito ao homem branco - no caso, Branca.

Todas essas contradições sociais que se amarram ao nacionalismo romântico do Brasil - e, no caso dessas duas obras, um livro de história e um drama com contexto histórico bem delimitado (o período colonial) - apresentam o modo como o romantismo desse país está vinculado ao passado colonial, vivendo a partir dessa base exploratória e escravizatória. Como diz Alfredo Bosi em Dialética da colonização (1992, p. 60): "o processo de modernização das elites conheceu outras formas, aparentemente mais duras, no interior da situação colonial". É nesse processo dialético de uma fundação histórico-colonial que (sem uma liberdade potente) se sedimenta o processo de modernização dos ideais românticos no Brasil. E, apesar de participar do 
empenho de institucionalização do teatro nacional e trabalhar em órgãos do Império, como o IHGB e o Imperial Colégio Pedro II, Macedo está completamente inserido no jogo político dessas instituições que visam reforçar um sentimento de nação, trazendo a figura do índio como imagem alegórica do "bom selvagem", carente de catequese, sem dar-lhe a possibilidade de uma liberdade real. Ou seja, o destino de Cobé, assim como o dos escravizados dos oitocentos, era a servidão eterna ou o suicídio.

Como explica Luiz Costa Lima em sua Trilogia do controle: o Controle do imaginário (2007, p. 147), o romantismo brasileiro viveu um radical controle do imaginário e, ao contrário do alemão, não experimentou uma dialética de autorreflexão: "a dialética entre observação e autorreflexão cede a vez ao arco estreito formado por observação e sentimentalidade." Acontece que a sentimentalidade toma lugar de uma práxis autorreflexiva. Há dor tanto em Cobé, de Macedo, como em Mãe, de Alencar. Entretanto, não se vê a liberdade experimentada pelos personagens. Ambos se suicidam não por terem chegado a alguma reflexão niilista da existência, ou por uma ação volitiva (pois que essa só pertence ao homem branco) em busca de uma liberdade para além da vida. São suicídios sociais que estão apoiados na impossibilidade de mudança da realidade concreta dos personagens. Também não são políticos, porque se conformam com a realidade social e não reivindicam mudança de estrutura ou revolução. Isso não significa que não haja revolta e revolução dos negros e indígenas escravizados no contexto dos oitocentos, mas que a imaginação crítica de Macedo estava controlada.

Todavia, apesar de o controle do imaginário se mostrar flagrante na obra de Joaquim Manoel de Macedo, nota-se que o discurso ficcional de Cobé ultrapassa em reflexão o histórico de Lições de história do Brasil, dando a ver, pois, maior sensibilidade quanto ao ajuizamento da importância do indígena na história brasileira. Pela liberdade do ficcional, mesmo que controlada, Macedo é capaz de formular uma discursividade mais abrangente para o indígena no seu drama. Enquanto o discurso histórico do manual o sobrepuja, sem dar voz ao índio, a peça questiona o lugar de dominação territorial do homem branco. Macedo, como Alencar em Mãe, pelo ethos ficcional, produz um discurso empático a favor da vítima - o que não significa haver uma potência de transformação real, visto que o horizonte de sentimentalidade social não dá espaço para uma 
autocrítica do lugar de privilégio dos dramaturgos: Joana é uma espécie de "Virgem Maria" escravizada, e Cobé um Cristo, ambos destinados ao martírio. São vítimas de uma condição inelutável, e a comiseração sentimental dos dramaturgos desenha os personagens e impossibilita o horizonte de suas ações. Em Cobé há uma observação social da condição de escravização do presente transposta (mesmo que sem consciência plena) para o contexto colonial, mas não há autorreflexão acerca dos próprios limites estruturais que vinculam e aprisionam o imaginário do dramaturgo no interior dessa situação colonial.

Assim, as contradições da abordagem da forma dramática, com suas possibilidades dialógicas e a orientação didático-pedagógica do livro de história (homogeneizando o discurso histórico para o aluno primário), se apoiam em uma mentalidade formada por uma visão de mundo escravocrata do Oitocentos no Brasil. Entretanto uma mentalidade não é um todo coerente; ela possui nuances, contradições, desvios. E o esforço desta análise foi o de discutir as contradições internas de um mesmo recorte historiográfico (o período colonial do Brasil) escolhido e tratado por Joaquim Manuel de Macedo em duas obras, apresentando como elas se organizam e produzem suas singularidades em meio às suas diferenças e semelhanças.

Sem repetir chavões judicativos que veem a obra dramática, historiográfica e os romances do autor como um todo coeso, como se a análise das obras já estivesse aprioristicamente formatada pelos estudos históricos da intelectualidade brasileira do século XIX (que aproximam Joaquim Manuel de Macedo do pensamento de Francisco Adolfo de Varnhagen), ou pelas discussões crítico-historiográficas do teatro (que o ligam à ideia do gosto do público), o que se priorizou aqui foi dar ênfase a uma análise direta dos textos, compreendendo suas ideias centrais e diferenciando o tratamento dado pelo autor a um mesmo tema: o indígena no período colonial.

Seguiu-se intencionalmente esse mote de análise de não formular uma categoria, mas de deixar visível uma distância entre o Macedo historiador e o dramaturgo. Entendeu-se que essa diferença se opera pelo fato de o historiador e o dramaturgo se coadunarem em uma figura genérica - o homem das letras, o escritor profissional - que, não sendo um historiador especializado, algo próprio do século XIX no Brasil, organiza seu pensamento histórico tateando pragmáticas distintas de cada obra. Cada texto tem uma lógica e 
cada lógica textual conforma um pensamento. É, portanto, nessas conformações distintas que os desvios entre o historiador e o dramaturgo são verificados, compondo as nuances de um pensamento histórico que não é visível apenas na prática do historiador, mas também no confronto dessas máscaras vestidas pelo homem das letras em cada texto. Tal mascaramento do escritor - ora como historiador, ora como dramaturgo - deve ser entendido para que se compreenda o ethos intelectual de Joaquim Manuel de Macedo.

\section{Referências bibliográficas}

ALENCAR, J. Mãe. Rio de Janeiro: Tipografia Paula Brito, 1862.

ALENCASTRO, L. F. Vida privada e ordem privada no Império. In: ALENCASTRO, L. F.; NOVAIS, F. A. História da vida privada no Brasil. Império: a corte e a modernidade nacional. São Paulo: Companhia das Letras, 1997. v. 2. p. 11-93.

ALMEIDA, M. R. C. Os índios na história do Brasil no século XIX: da invisibilidade ao protagonismo. Revista História Hoje, São Paulo, v. 1, n. 2, p. 21-39, 2012.

AGAMBEN, G. Infância e história: destruição da experiência e origem da história. Tradução Henrique Burigo. Belo horizonte: Editora UFMG, 2008.

ASSIS, M. Obras completas de Machado de Assis: crítica teatral. Rio de Janeiro: Livro do Mês, 1961.

BAKHTIN, M. Estética da criação verbal. Tradução Paulo Bezerra. São Paulo: Martins Fontes, 2003.

BOSI, A. Dialética da colonização. 4. ed. São Paulo: Companhia das Letras, 1992. BOSISIO, R. A. D. Entre o escritor e o historiador: a história do Brasil imperial na pena de Joaquim Manuel de Macedo. 2007. 150 f. Dissertação (Mestrado em História) - Instituto de Filosofia e Ciências Sociais, Universidade Federal do Rio de Janeiro, Rio de Janeiro, 2007.

CAFEZEIRO, E.; GADELHA, C. História do teatro brasileiro: um percurso de Anchieta a Nelson Rodrigues. Rio de Janeiro: Funarte, 1996.

CALDEIRA, A. P. S.; MACEDO, A. M. C. Ramiz Galvão, historiador e bibliotecário: práticas e lugares da produção historiográfica no Brasil de fins do século XIX e início do século XX. História da Historiografia, Ouro Preto, n. 22, p. 43-58, dez. 2016. Disponível em: <https://goo.gl/8V64Vw>. Acesso em: 3 abr. 2017.

COSTA LIMA, L. Trilogia do controle: o controle do imaginário. Rio de Janeiro: Topbooks, 2007.

FOUCAULT, M. A arqueologia do saber. 7. ed. Tradução Luiz Felipe Baeta Neves.

Rio de Janeiro: Forense Universitária, 1987. 
MACEDO, J. M. Lições de história do Brasil para uso de escolas de instrução primária. Rio de Janeiro: Livraria Garnier, 1861. . O novo Otelo. Rio de Janeiro: [s.n.], 1863. Noções de corografia do Brasil. Rio de Janeiro: Livraria Garnier, 1873. Lições de história do Brasil para uso de escolas de instrução primária. 9. ed. Rio de Janeiro: Livraria Garnier, 1905. Cobé. In: Joaquim Manuel de Macedo: teatro completo. Rio de Janeiro: Funarte, 1979. (Coleção Clássicos do Teatro Brasileiro). t. 2.

MAQUIAVEL, N. O príncipe. Tradução Maurício Santana Dias. São Paulo: Companhia das Letras, 2010.

MATTOS, S. R. A história do ensino de história do Brasil no Império através dos manuais de Joaquim Manuel de Macedo. Rio de Janeiro: Fundação Getúlio Vargas, 1993.

MICHELAN, K. B. Ceuta, para além da terra dos mouros: a fabricação histórica de um marco do império português (século XV e início do XVI). 2013. 224 f. Tese (Doutorado em História) - Universidade Paulista Júlio Mesquita Filho, Faculdade de Ciências Humanas e Sociais, Franca, 2013.

ROCHA, J. C. C. Uma teoria de exportação? Ou: "Antropofagia como visão do mundo". In: RUFINELLI, J.; ROCHA, J. C. C. (Org.). Antropofagia hoje? Oswald de Andrade em cena. São Paulo: É Realizações, 2011.

SECO, A. P. A educação que emerge dos livros de viagens. In: REUNIÃO DE 20 ANOS

DO HISTEDBR (1989-2006), 2006, Campinas. Anais eletrônicos... Campinas: Unicamp, 2006. p. 1-25. Disponível em: <https://goo.gl/v5gBbj>. Acesso em: 2 fev. 2017.

SZONDI, P. Teoria do drama moderno [1880-1950]. Tradução Luiz Sérgio Repa. São Paulo: Cosac \& Naify, 2001.

TURIN, R. Tempos cruzados: escrita etnográfica e tempo histórico no Brasil oitocentista. 2009. 242 f. Tese (Doutorado em História) - Universidade Federal do Rio de Janeiro, Rio de Janeiro, 2009.

VARNHAGEN, F. A. História geral do Brasil. Rio de Janeiro: Casa de E. \& H. Laemert, 1854. t. 1.

Recebido em 01/09/2017

Aprovado em 14/05/2018

Publicado em 29/06/2018 